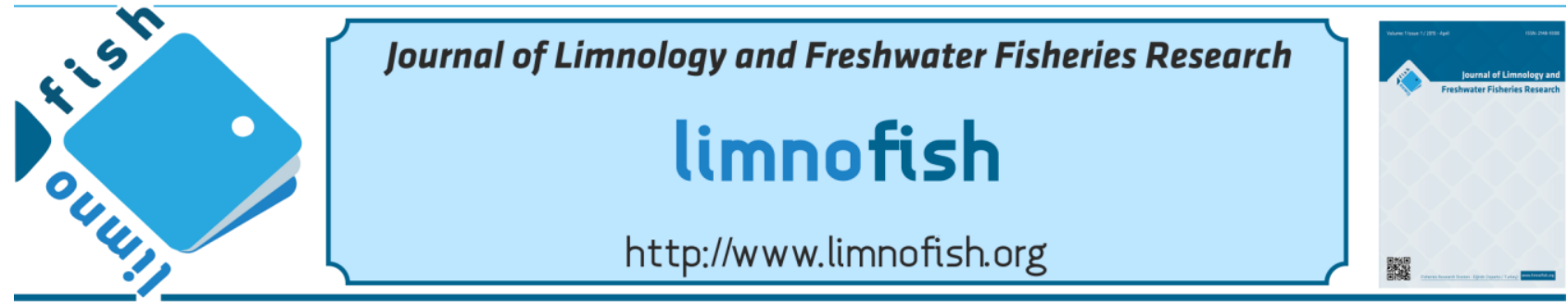

\title{
Eğirdir Gölü Makrofitlerinin Gelişme ve Yayılma Özelliklerinin Sualtı Gözlemleri ile İzlenmesi
}

\author{
Yıldız BOLAT ${ }^{1 *}$, Habil Uğur KOCA ${ }^{1}$, Ufuk Gürkan YILDIRIM ${ }^{1}$, Yaşar ÖZVAROL ${ }^{2}$, İ. İbrahim TURNA ${ }^{1}$, \\ Erhan ŞENER ${ }^{3}$, Vedat YEĞEN ${ }^{4}$, Fuat BILLGIN ${ }^{4}$, Hasan BOSTAN ${ }^{5}$ \\ ${ }^{1}$ Süleyman Demirel Üniversitesi, Eğirdir Su Ürünleri Fakültesi, Isparta, Türkiye \\ ${ }^{2}$ Akdeniz Üniversitesi, Su Ürünleri Fakültesi, Antalya, Türkiye \\ ${ }^{3}$ Süleyman Demirel Üniversitesi, Mühendislik Fakültesi, Isparta, Türkiye \\ ${ }^{4} \mathrm{Su}$ Ürünleri Araştırma Enstitüsü, Eğirdir-Isparta, Türkiye \\ ${ }^{5}$ Anamur İlçe Gıda Tarım ve Hayvancılık Müdürlüğü-Mersin, Türkiye
}

\section{$\ddot{O} Z$}

$\mathrm{Bu}$ çalışmada; Eğirdir gölündeki makrofitlerin gelişme ve yayılma özellikleri sualtı görüntüleme çalışmaları ile tespit edilmiştir. Ayrıca suyun fiziko-kimyasal değerleri de tespit edilerek bitki bioması üzerine etkili parametre belirlenmiştir. 2011 ve 2012 y1llarında ortalama sicaklık $21{ }^{\circ} \mathrm{C}$, oksijen $11,48 \mathrm{mg} / \mathrm{l}, \mathrm{pH} 9,4$, elektriksel iletkenlik $385,6 \mu \mathrm{S} / \mathrm{cm}$, organik madde $21,9 \mathrm{mg} / \mathrm{l}$, klorofil- $a 0,7$ $\mathrm{mg} / \mathrm{m}^{3}$, görünürlük, $2,73 \mathrm{~m}$, ortalama biomas $413,4 \mathrm{~g} / \mathrm{m}^{2}$ olarak bulunmuştur. $\mathrm{Su}$ derinliği 2011 yılında $52 \mathrm{~cm}$ ve 2012 yılında $55 \mathrm{~cm}$ azalmıştır. Bitkilerin gelişimi ve yayılması üzerine etkili parametrenin derinlik azalması olduğu belirlenmiştir.

Anahtar kelimeler: Makrofit, fiziko-kimyasal parametreler, büyüme ve yayılma, sualtı izleme, Eğirdir Gölü.
MAKALE BILGISI

$\begin{array}{ll}\text { ARAŞTIRMA MAKALES } \\ \text { Geliş } & : 01.07 .2015 \\ \text { Düzeltme } & : 02.11 .2015 \\ \text { Kabul } & : 06.11 .2015 \\ \text { Yayım } & : 20.12 .2015\end{array}$

DOI: 10.17216/LimnoFish-5000128523

* SORUMLU YAZAR

yildizbolat@sdu.edu.tr

Tel : +902462118682

Faks: +902462118697

\begin{abstract}
Monitoring by Underwater Observations of the Growth and Spread of Macrophytes in Eğirdir Lake-Turkey
Abstract: In this study, the growth and spread characteristics of macrophytes were identified by sub-water monitoring studies in Eğirdir Lake. Also, physicochemical parameters that effect on plant biomass were determined. The average temperature of $21{ }^{\circ} \mathrm{C}$, oxygen $11.48 \mathrm{mg} / \mathrm{l}, \mathrm{pH} 9.4$, electrical conductivity $385.6 \mathrm{mS} / \mathrm{cm}$, organic matter, $21.9 \mathrm{mg} / \mathrm{l}$, chlorophyll-a $0.7 \mathrm{mg} / \mathrm{m}^{3} \mathrm{visibility,} 2.73$ $\mathrm{m}$, the average biomass was $413.4 \mathrm{~g} / \mathrm{m}^{2}$ between 2011 and 2012 . The water depth in 2011 decreased by $52 \mathrm{~cm}$ and $55 \mathrm{~cm}$ in 2012 . The most effective parameter on the growth and spread of plants was found as decrease in the water depth.
\end{abstract}

Keywords: Macrophytes, physicochemical parameters, growth and spread, sub-water monitoring, Eğirdir Lake

\section{Alıntılama}

Bolat Y, Koca HU, Yıldırım UG, Özvarol Y, Turna İ̈, Şener E, Yeğen V, Bilgin F, Bostan H. 2015. Eğirdir Gölü Makrofitlerinin Gelişme ve Yayılma Özelliklerinin Sualtı Gözlemleri ile İzlenmesi. LimnoFish. 1(3): 103-111. doi: 10.17216/LimnoFish-5000128523

\section{Giriş}

Türkiye çok sayıda akarsu ve gölleri, çeşitli iklimsel özellikleri, jeolojik ve topografik farklılıkları ve değişik bitki coğrafyası bölgelerinin kesişme noktasında olması gibi nedenlerle dünyanın bitki çeșitliliği yönünden en zengin ülkeleri arasında yer almaktadir. Ancak bir kitada rastlanabilecek kadar çok bitki Türkiye'de bulunduğu için ülkemiz bitki çeşitliliği yönünden bir kita özelliği göstermektedir (Cirik vd. 2005). Su bitkileri deyimi olarak Hidrofit kelimesi ilk olarak 1822 yılında
Schouw tarafından doğal yaşama ortamı su olan bitkiler için kullanılmıştır. İlk yıllarda bu anlam altında suda yaşayıp da serbest yüzen, tamamen su altında veya bir kısmı su altında bir kısmı su üstünde bulunan tüm bitkiler toplanmıştır (Güner 1985).

Sucul ortamın asıl üreticileri olan su bitkileri bir hücreliden çok hücrelilere kadar çeşitli şekilleri olan ve klorofil içeren canlılardır. Ortamın dengesinin korunmasındaki önemleri büyüktür. Birincil üreticiler olarak tanımlanan yeşil bitkiler ve fitoplanktonik organizmalar klorofilleri sayesinde su 
ve suda eriyik halde bulunan karbondioksidi 1 ş1k enerjisi kullanarak fotosentez olayı sonucu organik madde üretimini sağlarlar. Böylece bitkisel protein kaynaklarını oluştururlar. $\mathrm{Bu}$ nedenle sucul ortamdaki besin zincirinin ilk halkasıdır. Bitkisel protein kaynağı olan bu mikroskobik ve makroskobik yeşil bitkiler daha sonra gida zincirinde hayvansal proteine dönüştükleri için çok önemlidir. Makrofitler tatlısu yaşamından organizmalara değişik habitatlar, barınaklar, tutunma ortamları hazırladıkları gibi bu canlıların doğrudan ve dolaylı olarak gıdalarını oluştururlar. Bu bitkilerin bazıları ayrıca balıkların hatta insanların dahi doğrudan beslenmesinde önemlidir. Örneğin, pirinç bitkisinde olduğu gibi tropikal bölgelerde birçok yabani tür yerliler tarafından yenilir, birçoğundan hasır, çadır ve çatı yapımında, evcil hayvanların beslenmesinde, hastalıkları iyileştirmede ve tarlalarda gübre olarak kullanılır. Farklı yararları, kullanım alanları, zararları ve davranışları nedeniyle su bitkilerinin önemi büyüktür (Cirik vd. 2005).

Göllerde bulunan canlı kaynaklar arasında hayvansal organizmalar yanında bitkisel organizmalarda önemli yer tutmaktadır. Bitkisel organizmaların tür sayısı ve bulunma sıklığı o gölün verimliliği hakkında önemli bilgiler vermektedir. Özellikle bir gölde bitkisel organizmaların az ya da fazla bulunuyor olması, o gölün kullanım amacını belirlemek bakımından çok önemli bir gösterge olabilmekle birlikte, gölün oluşumundan itibaren geçirdiği evrimin neresinde olduğu konusunda da araştırıcılara bilgi verebilmektedir. Kimi zaman verimlilik göstergesi olabilen bitkisel organizmalar, çevre dengesini bozacak düzeyde artmaları sonucunda kirlilik ve göl sisteminin yok oluşunun da göstergesi olarak değerlendirilebilmektedir. Eğirdir Gölü'nde son yıllarda su bitkilerinin bölgesel dağılımında artış olduğu gözlenmektedir. Bu çoğalmanın ekolojik denge açısından bir uyarı olduğu düşünülebileceği gibi, ticari balık avcılığını da yakından ilgilendirmektedir. Planlanan çalışmanın temel amac1, göldeki bitki potansiyelinin büyüme ve gelişme özellikleri ile dağılımının ve yayılma alanının iki yıllık süreçte tespit edilmesidir.

\section{Materyal ve Metot}

$\mathrm{Bu}$ çalışmada, sualtı fotoğraf çekimleri ve örneklerin temini için araştırma bölgesinde scuba dalışlar gerçekleştirilmiştir.

Sualtı çekimlerinde 300 lümen LED aydınlatmalı, Rioharm $0,45 \times 30 \mathrm{~mm}$ geniş açı lens tak1lı olan Sony HDR-CX115 1080 p kamera ve Viper sualtı kabı kullanılmıştır.

Kısa makrofitlerin alınmasında Ekman kepçesi kullanılmıştır. Alınan örnekler, bitkilere yapışan artıklar, algler ve dipten gelen çamur tabakasının temizlenmesi için yıkanmıştır. Yıkanan örnekler, fazla suyun alınması için kurulanmış ve polietilen torbalarda muhafaza edilerek etiketlenmiştir. Çalışma tür teşhisine yönelik bir çalışma olmadığı için alınan bitki örnekleri laboratuvara getirildikten sonra lup, stereomikroskop ve binoküler mikroskop kullanılarak incelenmiş ve önceki çalışmalarda tür teşhisleri yapılmış olanlar ile karşılaştırılmıştır (Lund vd. 1958; Seçmen ve Leblebici 2008; Güner vd. 2012). Sucul bitki biyokütlesi birim alanda yaş ve kuru ağırlık bazında belirlenmiştir. Makrofitler türlerine göre ayrıldıktan sonra hassas terazi ile yaş ağırlıkları tartılmış ve $\mathrm{m}^{2}$ 'deki yaş ağırlıkları belirlenmiştir. Bitki yoğunluğunun su seviyesine bağlı değişimlerini belirlemek amaciyla $6 \mathrm{~m}$ derinliğindeki istasyon örnek olarak seçilmiştir. Örnekleme periyodu boyunca bu istasyondaki aylara göre su seviyesindeki dalgalanmalar ve bitki yoğunluğunda görülen değişimler incelenmiştir.

$\mathrm{Bu}$ araştırma, Eğirdir Gölü' nün güney bölgesinde ve GPS ile belirlenen $37^{\circ} 50^{\prime} \mathrm{K}$ ve $30^{\circ} 51^{\prime} \mathrm{D}$ koordinatlarında tek bir istasyonda gerçekleştirilmiştir (Şekil 1). Bu istasyon, KuzeyGüney yönlerinden esen ve özellikle Güney-Batı yönünden esen Lodostan en az etkilenen, yüzey ve dip akıntısının en az olduğu ve en önemlisi makrofit yoğunluğunun fazla olduğu bir bölge olması nedeni ile seçilmiştir.

Fotoğraflama ve yoğunluk tahminlerini gerçekleştirmek için bölgede yapılan çalışmada, turuncu renkli ve üzeri $1 \mathrm{~m}$ aralıklarla işaretlenmiş 4 mm çaplı naylon halat NE yönünde alınan kerteriz istikametinde su altına uzatılmıştır. $6 \mathrm{~m}$ derinlikten kıyısal alana kadar olan bölgede dalgıçlar sualtı çekimlerini zeminden iskandil ile belirlenen yaklaşık 50-70 cm yukarıdan gerçekleştirmişlerdir.

Dalışlar sırasında dalgıçlardan biri çekimleri gerçekleştirirken, ikinci dalgıç ise çekimlerin tamamlandığı bölgeden bitki örneklerini toplamıştır. $0,5 \mathrm{~m}$ derinlik aralıkları ile $1 \mathrm{~m}^{2}$ lik alandan toplanan bitkiler poşetlerde muhafaza edilmiş ve aynı gün laboratuvarda tartılarak ağırlıkları kaydedildikten sonra yıkanarak temizlenmiş ve kurutulmuştur.

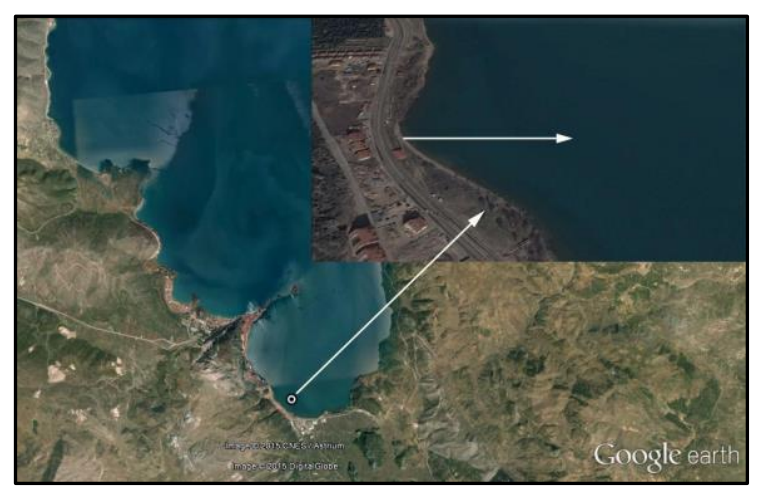

Şekil 1. Araştırma sahası. 
Görüntülenen alana ait videolarda kerteriz halatı üzerindeki işaretlerden yararlanılarak derinlikler belirlenmiş ve bilgisayar ortamında her yarım metre derinlik değişimine denk gelecek şekilde sabit görüntüler oluşturulmuştur. Daha sonra bu görüntüler kareleme metoduyla 100 eşit kareye bölünmüştür. Fotoğraf üzerindeki karelerin su bitkisi bulunduranları, dolulukları da dikkate alınarak sayılmış ve görüntüsü alınan alandaki bitki bulunabilirliği \% olarak ifade edilmiştir.

\section{Su Kalitesi Analiz Yöntemleri}

Klorofil-a: Araştırma istasyonlarından alınan 1 litrelik su örnekleri Whatman GF/A cam elyaf kağıdından Nuche erleni ve su trombu yardımıyla süzülmüştür. Plankton örnekleri ihtiva eden süzgeç kağıtları, petri kutuları içerisine konularak karanlık ortamda ve oda sicaklığında 3-4 saat kurumaya bırakılmıştır. Kuruyan süzgeç kağıtları makasla çok küçük parçalara bölünerek, içinde $15 \mathrm{ml} \%$ 90'lik aseton bulunan $50 \quad$ ml'lik erlenlere konmuştur. Ayrica ilave edilerek 3-4 ${ }^{\circ} \mathrm{C}$ 'de ve karanlıkta 24 saat özüte edilmiştir. Ekstraksiyon süresi sonunda özüt GF/A cam elyaf kağıdından süzülerek katı kısım atılmış, geri kalan sivinin pektrofotometrede 630,645 ve $665 \mathrm{~nm}$ dalga boylarındaki absorbsiyonları okunmuştur. Klorofil- $a$ miktarları aşağıdaki formüle göre klorofilin bozulmaması için $0,3 \mathrm{~g}$ susuz $\mathrm{MgCO}$ hesaplanmıştır.

$$
\text { Klorofil }-a\left(\mathrm{mg} / \mathrm{m}^{3}\right)=\frac{v\left(11,6 \mathrm{xD}_{665}-0,14 \mathrm{xD}_{630}-1,31 \mathrm{xD}_{645}\right)}{I \mathrm{x} V}
$$

$V$ Süzülen örnek suyun hacmi (litre), $v$ ekstraksiyon için kullanılan asetonun çözeltisi hacmi (ml) ve $I$ spektrofotometre küvetinin 1 şı yolu $(\mathrm{cm})$ (Gönülol 1985).

Organik Madde: Organik madde asitli ortamda permanganat ile yükseltgenip, çözeltinin rengi okzolat ile giderilerek, okzolatın fazlası permanganat ile geri titre edilerek yapılmıştır (Allen ve Minear 1982).

Derinlik: Gölün derinliği iskandil ile ve Suunto-Stringer dalış bilgisayarı ile ölçülerek metre cinsinden verilmiştir.

Işık Geçirgenliği: Suyun içerisine daldırılan sechi diskinin görünürlüğün kaybolduğu nokta ile değerlendirilmiş ve metre cinsinden verilmiştir.

Sicaklık: Su sicaklığ SCT-metre ve Suuntostringer dalış bilgisayarı ile tespit edilmiştir.

pH: Suyun pH'1 arazide WTW-set 320 pH metre ile tespit edilmiştir.

Çözünmüş Oksijen: Çözünmüş oksijen arazide WTW-set 320 oksijenmetre ile ölçülmüştür. Elektriksel İletkenlik: Suyun elektriksel iletkenliği
YSI 30 model SCT-metre ile ölçülmüş ve $\mu \mathrm{S} / \mathrm{cm}$ olarak ifade edilmiştir.

\section{Bulgular}

\section{Fiziko-kimyasal Parametreler}

Araştırmada ölçülen 2011-2012 yıllarına ait fiziko-kimyasal parametrelerin aylara göre ortalamaları Çizelge 1'de verilmiştir.

$\mathrm{Su}$ sicaklığındaki maksimum değer $25{ }^{\circ} \mathrm{C}$ (Ağustos), minimum değer $14{ }^{\circ} \mathrm{C}$ (Ekim) olarak tespit edilmiştir. Su sicaklığ 1 ortalama $21{ }^{\circ} \mathrm{C}$ dir. Eğirdir Gölü'ndeki çözünmüş oksijen ölçümlerine göre maksimum çözünmüş oksijen miktarı $15,8 \mathrm{mg} / 1$ (Ağustos), minimum çözünmüş oksijen miktarı $8 \mathrm{mg} / 1$ (Haziran) olarak tespit edilmiştir. Araştırma süresince gölde tespit edilen ortalama çözünmüş oksijen miktar1 11,48 mg/l'dir. Göldeki $\mathrm{pH}$ ölçümlerine göre maksimum $\mathrm{pH}$ değeri 9,8 (Haziran), minimum pH değeri 9 (Eylül) olarak tespit edilmiştir. Ortalama $\mathrm{pH}$ değeri 9,4 olarak saptanmıştır. Göldeki elektriksel iletkenlik ölçümlerine göre maksimum değer $396 \mu \mathrm{S} / \mathrm{cm}$ (Temmuz), minimum değer $375 \mu \mathrm{S} / \mathrm{cm}$ (Eylül)'dir. Ortalama elektriksel iletkenlik değeri 385,6 $\mu \mathrm{S} / \mathrm{cm}$ olarak bulunmuştur. Eğirdir Gölü'ndeki organik madde miktarı maksimum 24,3 mg/l (Eylül), minimum 16,9 mg/l (Temmuz)'dir. Göldeki ortalama organik madde miktarı $21,9 \mathrm{mg} / \mathrm{l}$ olarak saptanmıştır. Fitoplankton biyomas tayininde bir gösterge olarak kullanılan klorofil- $a$ miktarı Eğirdir Gölü'nde hesaplanan değerleri Çizelge 1'de verilmiştir. Araştırma süresince ölçülen klorofil- $a$ değeri en yüksek Eylül ayında $0,9 \mathrm{mg} / \mathrm{m}^{3}$, en düşük Haziran ayında $0,6 \mathrm{mg} / \mathrm{m}^{3}$ olarak bulunmuştur. Araştırma süresince bölgenin derinliği ölçülerek maksimum $6 \mathrm{~m}$ (Haziran), minimum 5,48 m (Ekim) olarak tespit edilmiştir. Ortalama derinliği 5,66 m'dir. Göldeki maksimum görünürlük 3,05 m (Ağustos), minimum görünürlük değeri 2,54 m (Eylül)'dür. Göldeki ortalama görünürlük 2,73 m olarak saptanmıştır.

Biomass değeri maksimum $517 \mathrm{~g} / \mathrm{m}^{2}$ (Eylül), minimum $226 \mathrm{~g} / \mathrm{m}^{2}$ (Haziran) olarak tespit edilmiştir. Biomass ortalama $413,4 \mathrm{~g} / \mathrm{m}^{2}$ dir.

\section{Bitki Türleri}

Yapılan çalışmada tespit edilen makrofit türler Şekil 2 'de verilmiştir.

\section{Bitkilerin Bulunurluk ve Biomas Dağılımı} 2011-2012 y1llarına ait derinliklere göre bitki bulunabilirliği değerleri Çizelge 2 ve Şekil 3,4'de, verilmiştir. 2011-2012 yıllarına ait derinliklere göre biomass değerleri Çizelge 3 ve Şekil 5'de verilmiştir. 
Çizelge 1. Eğirdir Gölü fiziko-kimyasal parametreleri.

\begin{tabular}{lcccccc}
\hline Parametreler & Haziran & Temmuz & Ağustos & Eylül & Ekim & Ort. \\
\hline Sicaklık $\left({ }^{\circ} \mathrm{C}\right)$ & 23 & 25 & 22 & 19 & 14 & 21 \\
Oksijen $(\mathrm{mg} / \mathrm{l})$ & 8 & 8,5 & 15,8 & 14,8 & 10,3 & 11,48 \\
$\mathrm{pH}$ & 9,8 & 9,5 & 9,2 & 9 & 9,3 & 9,4 \\
Elektriksel İletkenlik $(\mu \mathrm{S} / \mathrm{cm})$ & 385 & 396 & 382 & 375 & 390 & 385,6 \\
Organik Madde $(\mathrm{mg} / \mathrm{l})$ & 24 & 16,9 & 22,5 & 24,3 & 21,8 & 21,9 \\
Klorofil- $a\left(\mathrm{mg} / \mathrm{m}^{3}\right)$ & 0,6 & 0,64 & 0,62 & 0,9 & 0,72 & 0,7 \\
Derinlik $(\mathrm{m})$ & 6 & 5,73 & 5,59 & 5,51 & 5,48 & 5,66 \\
Secchi Görünürlüğü $(\mathrm{m})$ & 2,82 & 2,58 & 3,05 & 2,54 & 2,65 & 2,73 \\
Biomass $\left(\mathrm{g} / \mathrm{m}^{2}\right)$ & 226 & 370 & 499 & 517 & 455 & 413,4 \\
\hline
\end{tabular}

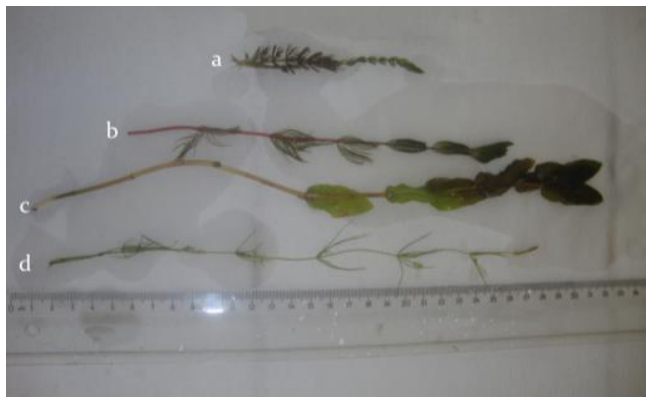

(a)

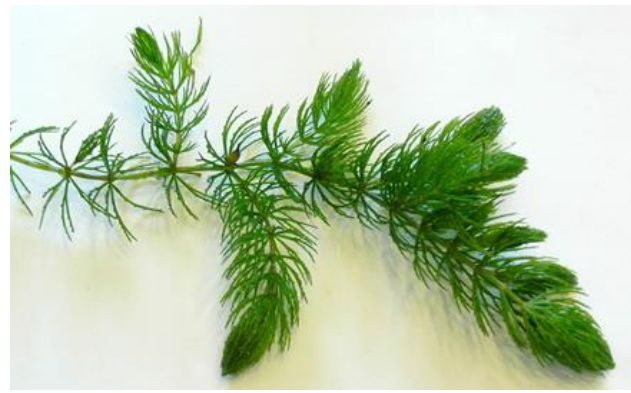

(b)

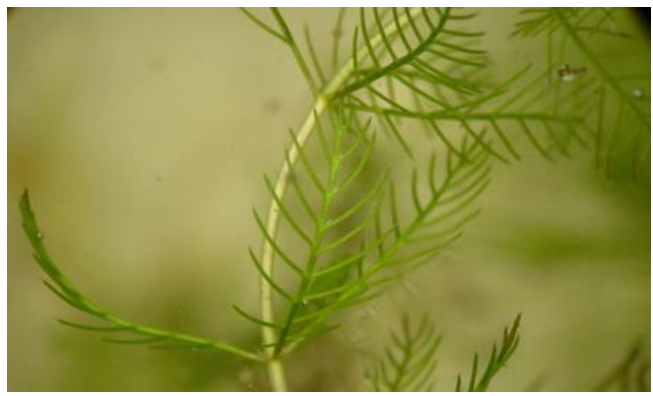

(d)

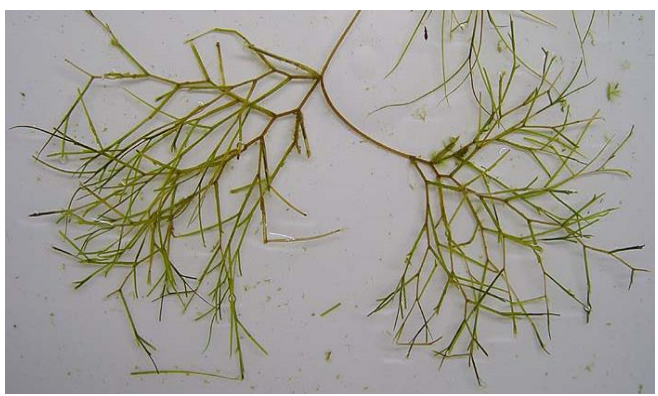

(c)

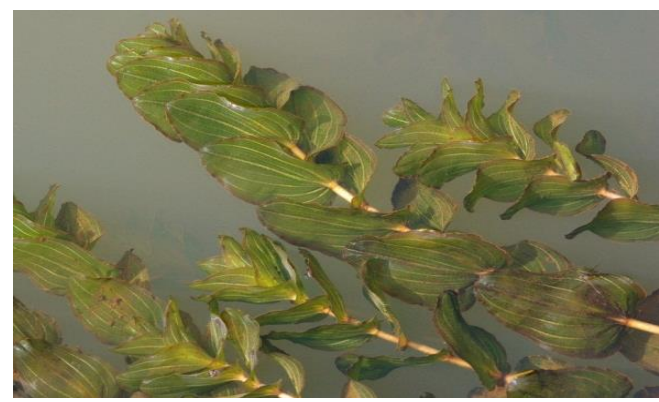

(e)

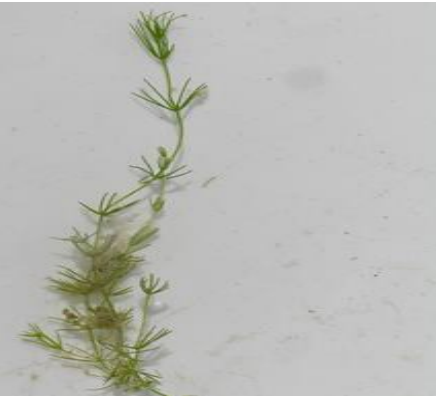

Şekil 2. Çalışmada tespit edilen makrofit türleri (a) Ceratophyllum demersum, (b) Myriophyllum spicatum, (c) Potamogeton perfoliatus, (d) Stuckenia pectinata (L,) Börner (Potamogeton pectinatus), (e) Chara sp (https://pt.wikipedia.org/wiki/Myriophyllum_spicatum; https://www.plantrescue.com; https://en.wikipedia.org/ wiki/Potamogeton_perfoliatus (Erişim Tarihi: 29/06/2015); http://www.theplantlist.org/tpl/record/kew309906/Stuckenia pectinata (23/10/2015); http://nathistoc.bio.uci.edu/Algae/Chara/index.htm (26/10/2015).

\section{Su Derinliği ile Bitki Yoğunluğu İlişkisi}

2011-2012 y1llarına ait bitki bulunabilirliği değerleri Şekil 6, 7'de verilmiştir. Yapılan çalışmalar sonucunda örnek olarak seçilen 6 m'lik istasyonun

derinliğinin aylara göre düşüş gösterdiği, bitki yoğunluğunun da bu değişime bağlı olarak artış gösterdiği tespit edilmiştir. 
Çizelge 2. 2011-2012 yılına ait derinliklere göre bitki bulunabilirliği değerleri (\%).

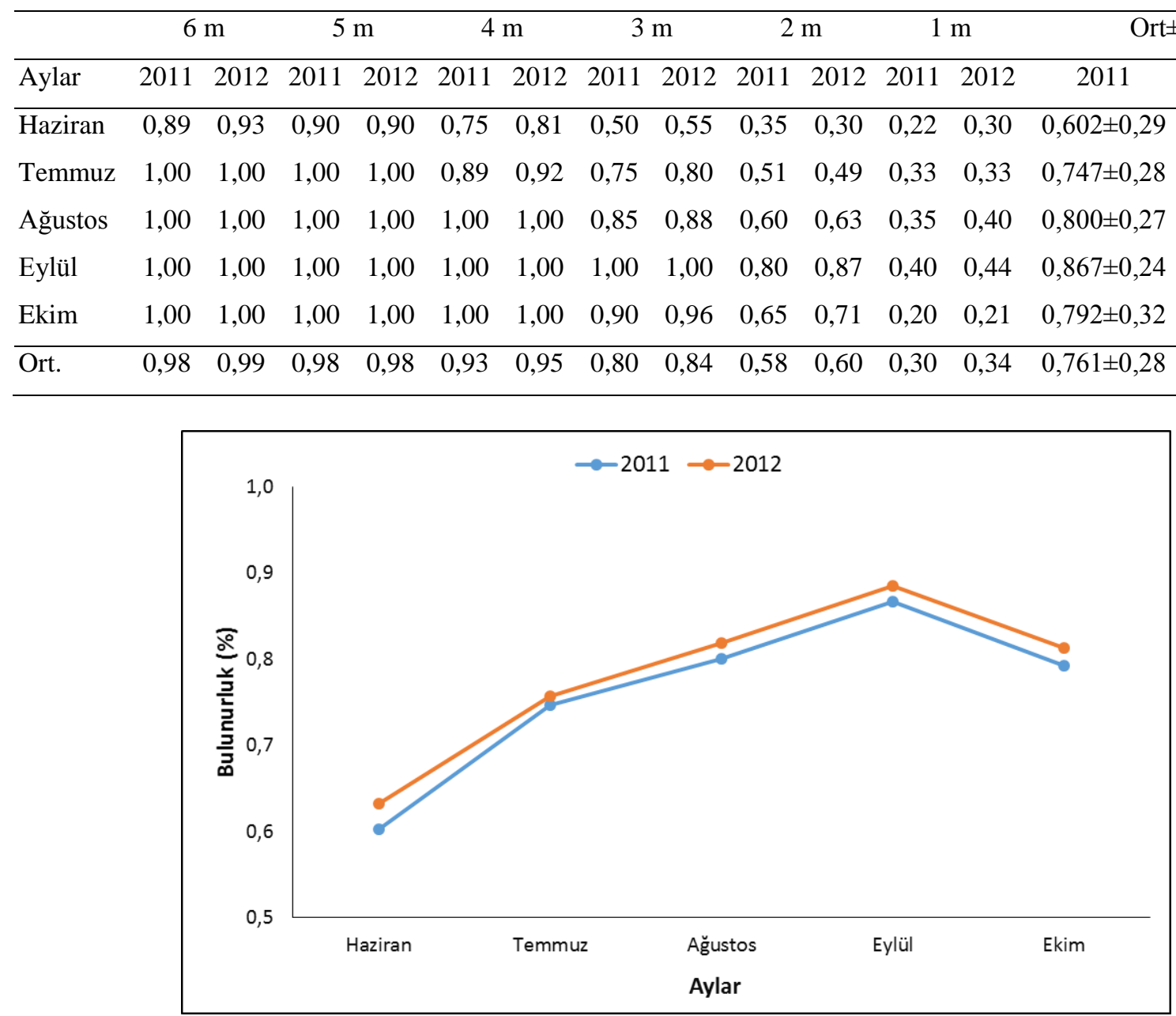

Şekil 3. 2011-2012 yıllarına ait aylara göre bitki bulunabilirliği grafiği (\%).
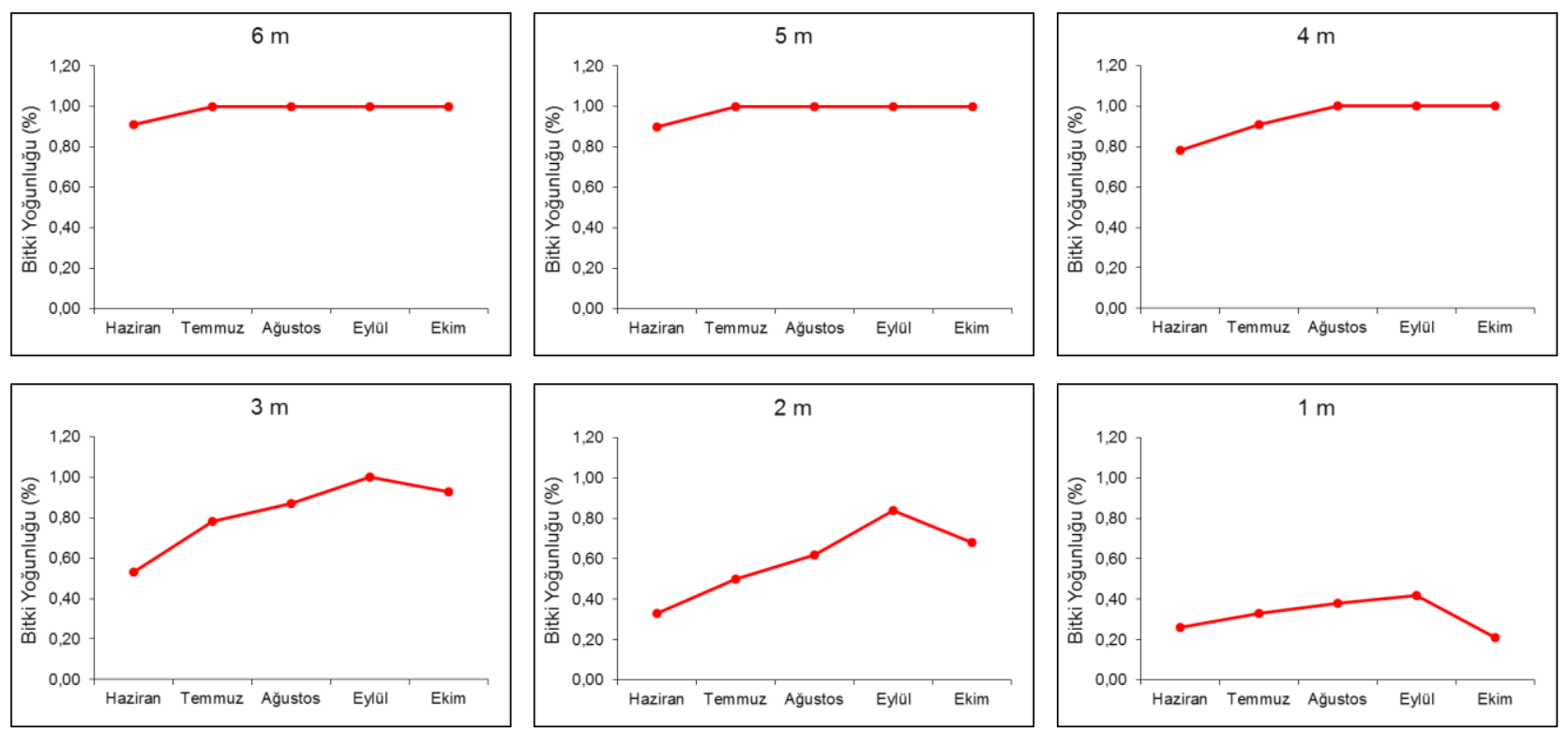

Şekil 4. 2011-2012 yıllarına ait ortalama yüzde bitki yoğunluğu grafiği. 
Çizelge 3. 2011 - 2012 yıllarına ait derinliklere göre biomass değerleri (g).

\begin{tabular}{lcccccccccccccc}
\hline \multicolumn{1}{c}{$6 \mathrm{~m}$} & \multicolumn{2}{c}{$5 \mathrm{~m}$} & $4 \mathrm{~m}$ & $3 \mathrm{~m}$ & $2 \mathrm{~m}$ & $1 \mathrm{~m}$ & Ort \pm STD \\
\hline Aylar & 2011 & 2012 & 2011 & 2012 & 2011 & 2012 & 2011 & 2012 & 2011 & 2012 & 2011 & 2012 & 2011 & 2012 \\
\hline Haziran & 250,0 & 282,0 & 275,0 & 296,0 & 312,0 & 325,0 & 285,0 & 305,0 & 115,0 & 126,0 & 65,0 & 83,0 & $217,00 \pm 101,59$ & $236,17 \pm 103,83$ \\
Temmuz & 415,0 & 456,0 & 482,0 & 520,0 & 502,0 & 550,0 & 356,0 & 384,0 & 295,0 & 312,0 & 76,0 & 95,0 & $354,33 \pm 156,70$ & $386,17 \pm 167,28$ \\
Ağustos & 580,0 & 681,0 & 640,0 & 712,0 & 686,0 & 737,0 & 485,0 & 503,0 & 373,0 & 389,0 & 95,0 & 115,0 & $476,50 \pm 218,02$ & $522,83 \pm 241,37$ \\
Eylül & 675,0 & 695,0 & 690,0 & 736,0 & 749,0 & 853,0 & 421,0 & 450,0 & 385,0 & 376,0 & 88,0 & 92,0 & $501,33 \pm 252,16$ & $533,67 \pm 281,37$ \\
Ekim & 599,0 & 620,0 & 670,0 & 655,0 & 691,0 & 808,0 & 388,0 & 401,0 & 256,0 & 298,0 & 24,0 & 56,0 & $438,00 \pm 264,87$ & $473,00 \pm 274,46$ \\
\hline Ort. & 503,8 & 546,8 & 551,4 & 583,8 & 588,0 & 654,6 & 387,0 & 408,6 & 284,8 & 300,2 & 69,6 & 88,2 & $397,43 \pm 198,67$ & $430,37 \pm 213,66$ \\
\hline
\end{tabular}

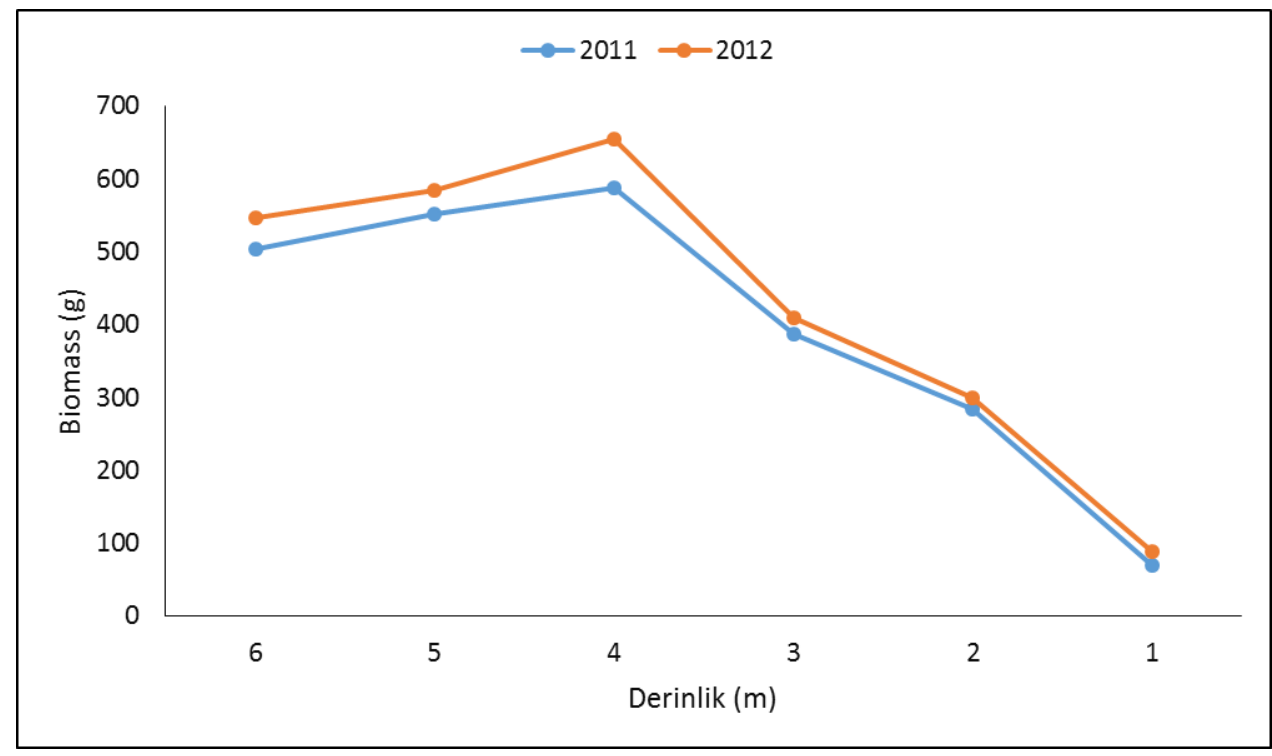

Şekil 5. 2011- 2012 yıllarına ait derinliğe bağlı biomass grafiği (g).

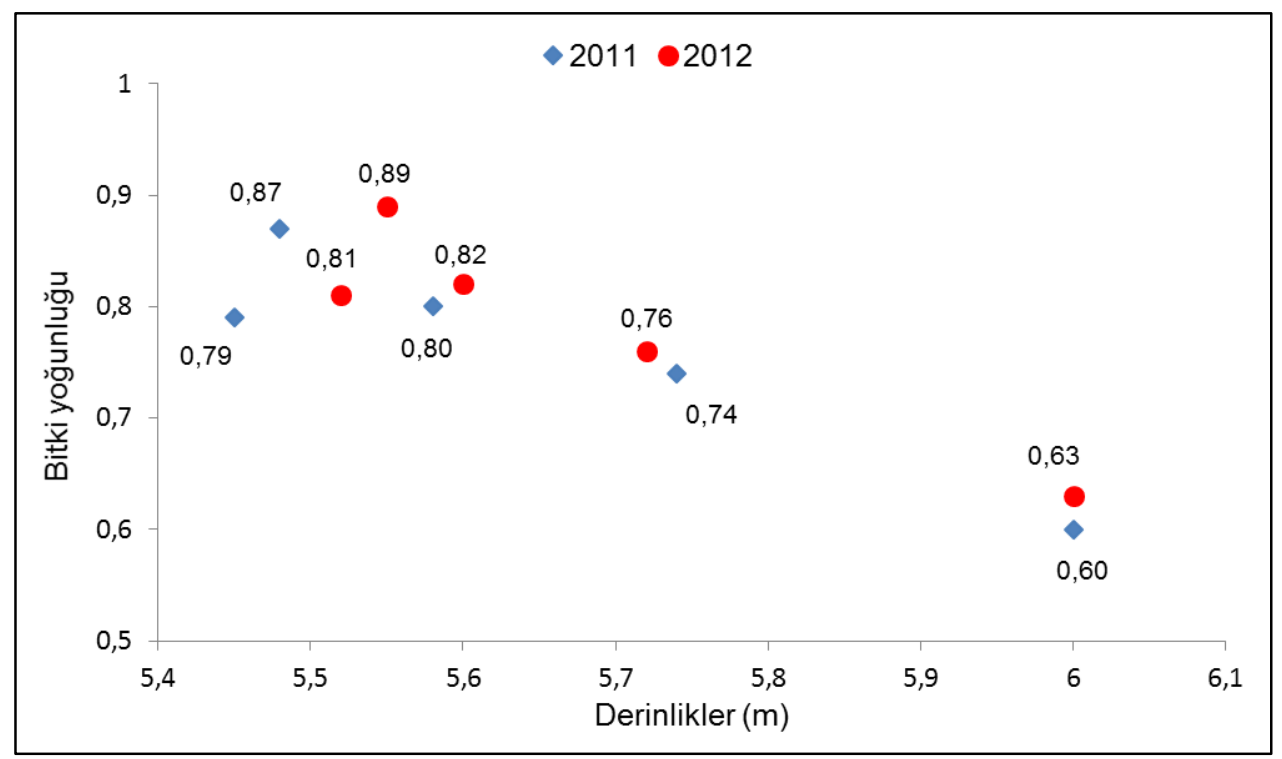

Şekil 6. Su derinliği değiş̧imi ile bitki yoğunluğu ilişkisi. 

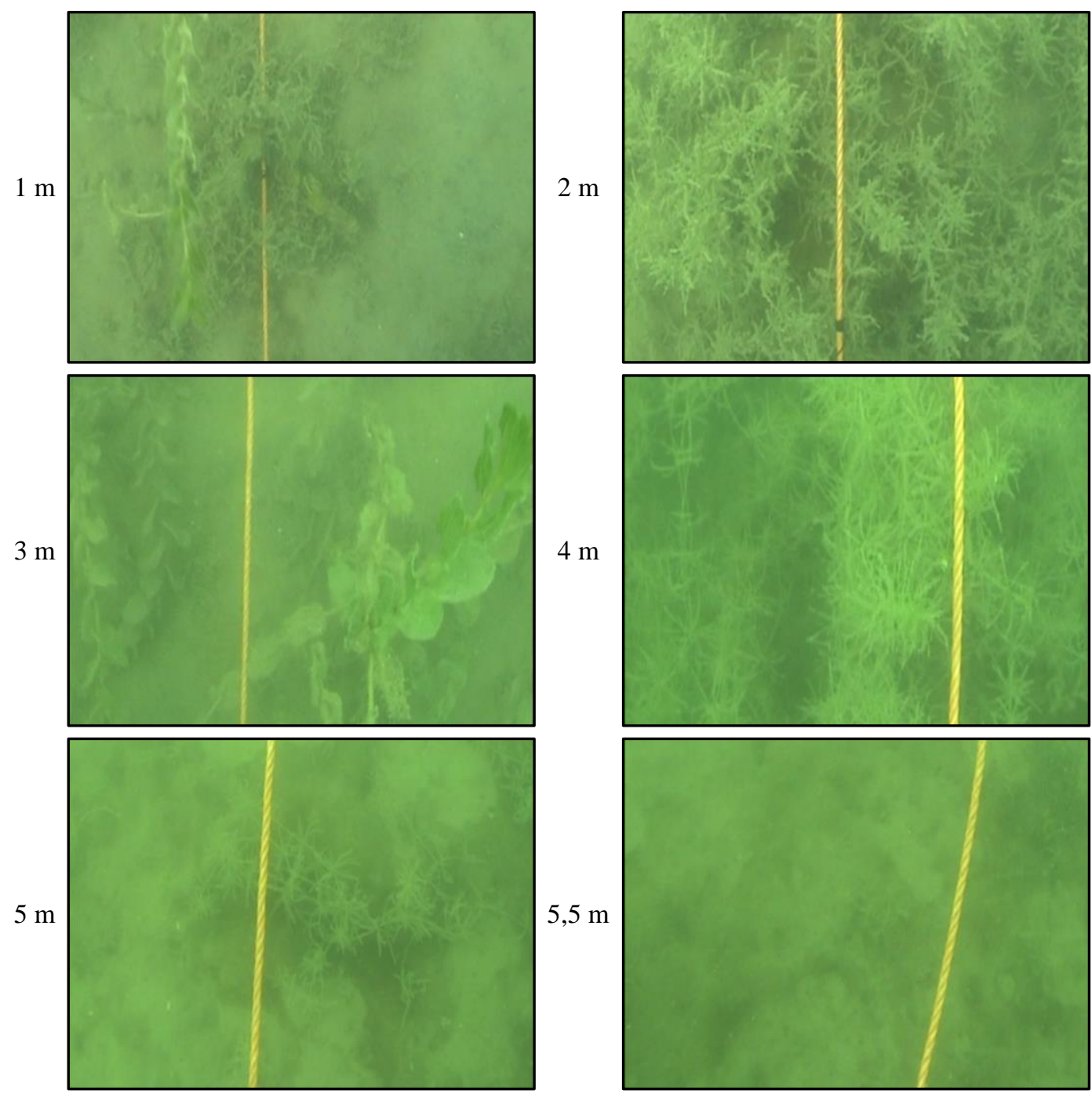

Şekil 7. Derinliğe bağlı bitki yoğunluğu görüntüleri.

\section{Tartışma ve Sonuç}

Eğirdir Gölü, Göller Bölgesi'nde Kuzey-Güney doğrultuda uzanan ve aynı yönlerden esen rüzgârların etkisi ile sı̆̆ bir göl olması nedeni ile tam karışımlı bir göl olup, yıl boyunca hareketli bir göldür. $\mathrm{Bu}$ nedenle sualtı kamera çekimleri ile yeterli netlikte görüntü alınabilmesi için en az 3 günlük sakin bir hava şartlarının hüküm sürmesini beklemek gerekmektedir ki, böyle bir periyot oldukça nadir ve kış aylarına rastlamaktadir.

Eğirdir Gölü'nde Secchi görünürlüğü özellikle birkaç günlük sakin hava şartları sonrası ölçüldüğü için araştırma süresince kararlı bir yapı sergilemiş ve ortalama görünürlük $2,73 \mathrm{~m}$ olarak belirlenmiştir.

Gölün su sıcaklığı bölgedeki hava sıcaklığına koşutluk göstermektedir. Yapılan ölçümlere göre yüzey suyundaki su sicaklığ ile $6 \mathrm{~m}$ derinlikteki sicaklık değerlerinde önemli bir farkl111k görülmemiştir. $\mathrm{Bu}$ durum, gölün derinliğe bağl1 olarak homojen bir yapıya sahip olduğunu ortaya koymaktadır.

Göldeki su sıcaklığı Haziran ayında $23^{\circ} \mathrm{C}$, Ekim ayında $14{ }^{\circ} \mathrm{C}$ ve ortalama $21{ }^{\circ} \mathrm{C}$ olarak ölçülmüştür.

Göl suyu pH'sı aylara bağlı olarak birbirine yakın değerler göstermiş olup, ortalama $\mathrm{pH} 9,4$ olarak saptanmıştır. Eğirdir Gölü'nde 1988-1997 yılları arasında yapılan çeşitli çalışmalarda $\mathrm{pH}$ değerinin 7,16-9,7 arasında değişim gösterdiği bildirilmiştir (Diler vd. 1997). Elde edilen bulgular önceki yılların değerlerine benzerlik göstermekte ve gölde pH değişimi yönünden önemli farklılıkların ortaya çıkmadığı görülmektedir.

Göldeki çözünmüş oksijen değeri ortalama 11,48 mg/1 olarak belirlenmiştir. Kış aylarına doğru çözünmüş oksijen miktarı yaz aylarına göre daha yüksek değerdedir. Gölde yapılan çalışmalara göre 1990-94 yıllarında çözünmüş oksijen miktarının 5,6-13,2 mg/l arasında değişim gösterdiği; 1997'de ise ortalama çözünmüş oksijenin 8,69 mg/1 
olduğu bildirilmektedir (Diler vd. 1997). Kazanc1 (1999), Eğirdir Gölü’nde yaptığı çalışmada, Haziran 1996 'da yüzey suyunun çözünmüş oksijen değerini 6,2; 4. m'de 6,2; 10 m.'de 6,6 mg/l olarak, Ocak 1997 'de yüzeyde 11,$5 ; 4$. m'de 11,3; 6. m'de 11,3 mg/l olarak; Mayıs 1998'de yüzeyde 6,9 mg/l olarak belirlemiştir.

$\mathrm{Su}$ ortamındaki anyon ve katyon miktarının bir göstergesi olan elektriksel iletkenlik su girdi ve çıktısına göre de değişimler gösterebilir (Uslu ve Türkman 1987). Bölgede yapılan çalışmalarda elektriksel iletkenliğin 117-472 $\mu \mathrm{S} / \mathrm{cm}$ arasında değişim gösterdiği bildirilmektedir (Diler vd. 1997). Elde edilen bulgular önceki çalışmalarla benzerlik göstermektedir.

Organik madde miktarı 16,9-24,3 mg/l olarak bulunmuş ve Eğirdir Gölü'ndeki organik madde miktarının önceki yıllarda bulunan ortalama değerlerin üzerinde olduğu 1997 yılındaki analiz sonuçlarına göre ortalama $10,47 \mathrm{mg} / 1$ düzeyinde (Diler vd. 1997), 12,0 mg/l (Kesici 1997) tespit edilmiştir.

Göldeki su giriş-çıkışının yüksekliği ve kuzeygüney rüzgarları nedeniyle, sürekli bir türbülans olmaktadır. Göl suyunun analiz sonuçları bu bilgilerle benzerlik göstermekte olup, bu durumun derinlik ve su giriş çıkışına bağlı olabileceği düşünülmektedir. Eğirdir Gölü'nde mevsimlere bağlı olarak giren ve çıkan su miktarındaki değişimler nedeniyle fiziksel ve kimyasal parametreler değişkenlik göstermektedir.

Eğirdir Gölü fitoplanktonu üzerine yapılan verimlilik ölçümlerinde; gölde klorofil- $a$ değerlerinin aylara göre birbirine yakın olduğu belirlenmiştir. Araştırma süresince Eğirdir Gölü istasyonlarında klorofil- $a$ değeri ortalama $0,7 \mathrm{mg} / \mathrm{m}^{3}$ olarak belirlenmiştir.

Eğirdir Gölü'ndeki makroflora ile ilgili çalışmalarımız süresince, yüksek bitkilerde farklı dağ 11 เm ve yoğunluğa rastlanılmıştır. Eğirdir Gölü'ndeki su seviyesinin yıllara göre farklılıklar göstermesi; gölün yüzölçümü, hacmi ve seviyesinde değişkenlikler oluşmasına neden olmaktadır (Kesici 1997). Göldeki bu su değişimleri, 1şığı̀n su seviyesine bağlı olarak yayılımı ve diğer çevresel koşullar bitki gelişiminde etkili olmaktadır (Kesici 1997; Kesici ve Ertan 1997). Ayrıca, substrat yapısı da bitki gelişimi ve yayılımı üzerinde etkilidir.

Araştırma bölgesinin $4 \mathrm{~m}$ ile $6 \mathrm{~m}$ derinlik aralığında zeminin kumluk, 2-4 m aralığında kumluçamurlu ve çakıllı bir yapının hakim olduğu kıyısal alanda ise çakıllı ve hatta çok iri taş ve kayalıkların varlığ dikkati çekmiştir. 1-1,5 $\mathrm{m}$ derinlikten 4-4,5 m derinliğe kadar kıyısal bölgede daha yoğun olmak üzere Chara sp. türü bitkilerin zemini yer yer kapladığı derinlere gidildikçe
Potamogeton, Myriophyllum ve Ceratophyllum türü bitkilerin çokluğu dikkati çekmiştir. Sıcaklık artışı ve su derinliğinin Temmuz ayı ile birlikte hızla azalmasına paralel olarak bitki yoğunluğunun da hızla arttığı biomasın Haziran ayında $226 \mathrm{~g} / \mathrm{m}^{2}$ ve Eylül ayında $517 \mathrm{~g} / \mathrm{m}^{2}$ olduğu tespit edilmiştir. $\mathrm{Su}$ derinliğinde 2011 yılında yaklaş1k $52 \mathrm{~cm}$ ve 2012 yılında $55 \mathrm{~cm}$ kadar bir azalmanın olduğu tespit edilmiştir. Fiziko-kimyasal parametreler ile biomas değerleri arasında yapılan çoklu regresyon analizine göre bitki yoğunluk artışında en önemli parametrenin derinlik azalması olduğu tespit edilmiştir.

Son yıllarda, Eğirdir Gölü'nde yaşanan hidrolojik dalgalanmaların (Kesici ve Kesici 2006), ihtiyofaunadaki değişimlerin (Küçük vd. 2006) ve trofi düzeyindeki artış eğiliminin (Aksoylar ve Ertan 2001, Gülle vd. 2008) vejetasyon üzerinde de önemli değişimlere neden olabileceği unutulmamalıdır.

\section{Teşekkür}

$\mathrm{Bu}$ çalışma 2604-M-10 nolu proje kapsamında SDÜ-BAP tarafindan desteklenmiştir.

\section{Kaynaklar}

Aksoylar MY, Ertan ÖO. 2001. Eğirdir Gölü'nün Hidrobiyolojik Özelliklerinin Tespiti, DPT Proje No:97K122330, Isparta.

Allen HE, Minear RA. 1982. Organic Constituens. Chapter IV, In M.J.Suess (Ed.) Examination Of Water Pollution Control Vol.2, Pergamon Press.London 358-499.

Cirik S, Cirik S, Conk-Dalay M. 2005. Su Bitkileri II, (İçsu Bitkilerinin Biyolojisi, Ekolojisi, Yetiştirme Teknikleri), Ege Üniversitesi Su Ürünleri fakültesi Yayınları No:61, Ders Kitab1 Dizini No:28, Bornova/İzmir.

Diler Ö, Altun S, Atay R. 1997. Eğirdir Gölü Su Kalitesi Fiziksel, Kimyasal, Mikrobiyolojik Parametreleri. Süleyman Demirel Üniversitesi Eğirdir Su Ürünleri Fakültesi Dergisi, 5: 1-34.

Gönülol A. 1985. Studies on the Phytoplankton of the Bayındır Dam Lake. Commun. Fac. Sci. Üniv. Ank. Serie C, Tome 3:21-38.

Gülle İ, Yıldırım MZ, Küçük F. 2008. Limnological History of Lake Eğirdir (Turkey) From 1950 s to the Present. Natura Montenegrina. 7(2):115-128.

Güner A, Akyıldırım B, Alkayış MF, Çıngay B, Kanoğlu SS, Özkan AM, Öztekin M, Tuğ GN. (2012). Türkçe bitki adları. Şu eserde: Güner, A., aslan, S. Ekim, T. Vural, M. \& Babaç, M.T. (edlr.). Türkiye Bitkileri Listesi (Damarlı Bitkiler). Nezahat Gökyiğit Botanik Bahçesi Yayınları Flora Dizisi 1 İstanbul.

Güner H. 1985. Hidrobotanik, Su Bitkileri, Ege Üniversitesi Fen Fakültesi Kitaplar Serisi No:91, Bornova/İzmir.

Kazancı N. 1999. Türkiye İç Sular Araştırma Dizisi: IV, Köyceğiz, Beyşehir, Akşehir, Eber,Kovada, Yarışl, Bafa, Salda, Karataş, Küçük ve Büyük Menderes 
Deltası, Güllük sazlı̆̆ı, Karamuk Bataklı̆̆g'nın Limnolojisi, Çevre Kalitesi ve Biyolojik Çeşitliliăgi" 372 s, Ankara.

Kesici E. 1997. Eğirdir Gölü Makrofitik Vejetasyonu Üzerine Fitososyolojik ve Ekolojik Bir Araştırma. S.D.Ü. Fen Bil. Enst. Doktora Tezi. 130, Eğirdir.

Kesici E, Ertan ÖO. 1997. Eğirdir Gölü Kayaağz1 Bölümünün Makrofitik Vejetasyonu. II. Spil Fen Bil. Kong. 23-25 Ekim. Celal Bayar Üniv. Fen Ed. Fak. Manisa.

Kesici E, Kesici C. 2006. The Effects of Interferences in Natural Structure of Lake Eğirdir (Isparta) to Ecological Disposition of the Lake. Journal of Fisheries \& Aquatic Sciences, 23 Suppl. (1/1): 99-103. Küçük F, Gülle İ, Güçlü SS, Gümüş E, Demir O. 2006. Eğirdir Gölü'ne Sonradan Giren Gümüş Balığ 1
(Atherina boyeri Risso,1810)'nın Göl Ekosistemine ve Balıkçılığa Etkisi. I. Ulusal Balıklandırma ve Rezervuar Yönetimi Sempozyumu 7-9 Şubat 2006, Antalya, 119-128s.

Lund JWG, Kipling C, Le Cren, ED. 1958. The inverted microscope method estimating algal numbers and statistical basis of estimations by counting. Hydrobiologia. 11(2):143-170. doi: 10.1007/BF00007865

Seçmen Ö, Leblebici E. 2008. Türkiye Sulak Alan Bitkileri ve Bitki Örtüsü, Ege Üniv., yayınları, fen Fakültesi yayın No:158. Ege Üniv. Basımevi, 450. Bornova-İzmir.

Uslu O, Türkman A. 1987. Su Kirliliği ve Kontrolu. T.C Başbakanlık Çevre Genel Müdürlüğü Yayınları Eğitim Dizisi 1. Ankara. $364 \mathrm{~s}$ 